\title{
An exploratory study of an early stage R\&D-intensive firm under financialization
}

\author{
Pauline Gleadle, The Open University* (m.p.r.gleadle@open.ac.uk)
}

Colin Haslam, The University of Hertfordshire+ (c.j.haslam@herts.ac.uk)

\begin{abstract}
The financialization literature considers the impact of financial markets on corporate strategy, governance, financial performance and the distribution of resources between various stakeholder groups. Capital market demands modify strategic priorities, governance and managerial narratives about performance because this helps justify value creation and value absorption in an era of shareholder value. The literature on financialization suggests that managers have a tendency to exaggerate performance to boost valuations especially when their interests align with those of the firmôs shareholders. In this exploratory study of an R\&D-intensive firm ñMedcoò we consider the extent to which managerial narratives and corporate governance of this $\mathrm{R} \& \mathrm{D}$ intensive firm reflect a process of financialization.
\end{abstract}

Key words: financialization, shareholder value, R\&D-intensive firms, bio-pharmas.

\section{Note}

To preserve anonymity we do not identify the name of the company that was the subject of our investigation. We also maintain the confidentiality of those we have interviewed.

\section{* Contact}

Dr Pauline Gleadle,

Lecturer in Management,

The Open University Business School

The Open University

Walton Hall

Milton Keynes MK7 6AA

UK.

Tel: $+0044(0) 1908655888$

Fax: +0044(0)1908 655898 .

+Professor Colin Haslam

Director, Centre for Research in Finance and Accounting (CRiFA)

University of Hertfordshire

Hatfield

Herts AL10 9AB

UK.

Tel: +0044(0)1707285 518 
An exploratory study of an early stage R\&D-intensive firm under financialization

\section{Introduction}

The established literature on shareholder value and financialization considers the impact of the stock marketsô increasing demands for financial returns on corporate behaviour, governance and performance (Froud et al, 2002; Andersson et al, 2007). Under financialization, the behaviour of firms is modified to create open dynamics and variable results distinguished by instability, reversibility and unpredictability (Gleadle \& Cornelius, 2008; Andersson et al, 2008). To date there have been few case studies of management control under financialization (see Ezzamel et al, 2008 for an exception) and of the impact of financialization on R\&D-intensive organizations (Lazonick, 2007). Froud et al (2006), for example, construct a case study on the financialization of strategy in the pharmaceutical giant, Glaxo Smith Kline (GSK), employing secondary sources rather than original narratives relating to issues of internal management control.

The aims of this exploratory case study are to investigate the extent to which an R\&D intensive firm, Medco, operates within a productionist or financialized framework of corporate governance (see Andersson et al, 2008). Our research objectives(s) are to explore the narratives and numbers connected with managing and operating this R\&D intensive biopharma company. Specifically, to what extent have corporate priorities, management culture and governance of this R\&D intensive company been modified by the demands of the capital market under financialization?

Our research takes a middle ground narratives and numbers approach that respects the selfinterpretations of the social actors interviewed and maintains a rich landscape / universe within which to review the relative financial performance of the case study firm, Medco. This case study reveals how narratives that constellate around $R \& D$ are modified by the demands of the capital market. Our analysis of the numbers makes visible the extent to which R\&D delivers superior corporate financial performance when we compare Medco against all other small caps listed on the Alternative Investment Market (AIM). Narratives and numbers are 
counterpoised to construct critical reflections about $R \& D$ under financialization where connections are not straightforward and outcomes ambiguous.

The paper adopts the following structure. First, we review the academic literature on R\&D observing that this is located within a óroductionistôframework where connections between performance, productivity and competitiveness for value creation are constructed. We then turn to discuss the method and general approach employed and how this addresses issues, for example, identified by Froud et al (2006) and Lazonick (2007). Our third section presents a summary of the interviews undertaken at Medco to reveal narratives about corporate performance. The fourth section reviews financial performance and considers the extent to which governance and stakeholder settlements align with a productionist or financialized enterprise. In the discussion and concluding remarks, we argue that notwithstanding Medcoôs relatively high $R \& D$ spend the company emerges as one which is financialized in nature.

\section{Literature review}

Both government policy documents and the academic literature identify the potential of the creative and innovative sectors to transform economic growth and national competitiveness (DCMS 1998, 2001, Lazonick and OôSullivan 2000, 2004, Prahalad and Hamel,1990). The general argument is that investment in innovation can help strengthen corporate financial performance and transform industry and national economic competitiveness. Investment in knowledge development and commitment to high levels of $R \& D$ spending is a key to maintaining competitiveness and closing the ñinnovation gapò.

Investment in research, leading to innovation and productive benefit to the economy, is a major concern for governments around the world, and a high priority for the European Union. Currently, the EU has considerable strengths, yet invests about a third less than the US and the innovation gap has not narrowed in recent years. http://www.eirma.org/f3/showthread.php?t=613

An alternative literature reveals how managerial behaviour and culture, corporate governance, stakeholder interests, firm performance, national economic competitiveness and the distribution of income and wealth are steadily modified by the demands of finance capital (Deeg \& OôSullivan 2006; Fligstein 2004; Froud et al, 2006; Rossman \& Greenfield, 2006; 
Stockhammer, 2004). Alternative financialized accounts of R\&D, innovation and performance engage with the general presupposition that $R \& D$ intensive firms are able to capture above average economic performance, growth and productivity that in turn reduce cost structures to boost profits and cash margins. In the Froud et al (2006) ñGlaxoò case accounting numbers are employed to reveal limited transformation in corporate financial performance, especially in key variables such as profit and return on capital employed (see also Andersson et al 2006). Froud et al (2006) explore discrepancies between managerial narratives about performance and alternative narrative(s) constructed out of company financial statements. Froud et al observe that the tendency of a shareholder value driven management culture is to provide flattering narratives about performance and thereby inflate capital market valuation and ñtalk up the value of the stockò.

More generally, the process of financialization presents a threat to sustaining investment in productive and process renewal because financial markets demand value creation and value absorption from invested capital. In an era of shareholder value managers are under pressure to both create value and absorb value for shareholders (Andersson et al, 2008; Lazonick and Oôsullivan, 2000). Andersson et al $(2007,2008)$ reveal that in both the US and Europe firms are distributing a higher share of cash resources to shareholders relative to productive capital expenditure in product and process renewal. Lazonick and OôSullivan (2000) describe, this as the strategy of ñdownsize and distributeò because the priority is to increase the share of profit and cash distributed to shareholders rather than to reinvest in product development and innovation.

\section{Research approach}

The aims of this exploratory study are to investigate whether our R\&D oriented firm Medco operates under a productionist or financialized form of corporate governance in the management of its operations and corporate strategy (Andersson et al, 2008). To this end, firstly, following Yin (1984) we conduct an exploratory case study of a successful medical diagnostics company in the South East. According to Yin (1984:13)

ácase studies are the preferred strategy when ónowô or ówhyô questions are being posed, when the investigator has little control over events, and when the focus is on a contemporary phenomenon within some real-life context.ô 
Often the goal of an exploratory case is to develop propositions and identify problems for further enquiry. To this end, we deliberately interviewed Medcoôs commercial director, a senior finance professional and three individuals from different levels within the laboratory R\&D function located within the Lab division based in the South East. This choice of interviewees facilitated an exploration of possible tension between commercial and financial objectives, and the organization of R\&D within Medco. In order to cross-check our findings, we perform some detailed financial analysis using key financial metrics taken from Medcoôs published accounts covering the 5-year period 2003-2007 when the company had just started operations. For the purposes of the current paper, although we are not comparing Medco with other bio-pharma, our approach resonates with Lazonick $\hat{Q}$ (2007:1027) call below:

ó..only in-depth studies at the company level, and ideally ones that are comparative among major competitors in an industry, can generate robust conclusions about the relation between the functions that the stock market performs in the corporate enterprise and the generation of innovative capabilities.ô

Lazonick continues (2007:1028)

áhe analysis of the relation of the stock market to innovative enterprise, therefore, must be not only firm-based and comparative; it must be historical as well.ô

In addition to the collection of narrative accounts to build our case study, we have constructed a relative financial performance profile of Medco against the Alternative Investment Market (AIM) group of companies. For the latter we construct a financial profile of 500 AIM listed firms that have disclosed 5 years of financial data for the period 2003 to 2007. This group of AIM-listed firms is employed as a reference group against which we can compare the performance of Medco. Our financial metrics utilize the nature of expenses rather than function of expense approach to profile financial performance. Starting with the revenue side, we deconstruct performance to reveal separately how much revenue is employed to cover external and then internal costs (such as employee expenses) leaving a residual of cash and profit from operations. We then combine this analysis with rates of capitalization (debt and equity) employed to generate a unit of cash or profit per unit of capital employed (Andersson et al, 2007, 2008). Triangulating these findings with the 
narratives provided by those interviewed, we construct an exploratory case study of Medco, an R\&D-intensive business, under conditions of financialization.

\section{The case study Medco}

\subsection{The industry: medical diagnostics}

The medical diagnostics industry is a specialized segment of the bio-pharma industry where firms are involved in the development of testing equipment and the associated chemical (the analyte or marker) which are employed to carry out the assay (the test). For example, a sample taken from a patient, such as blood or urine, can be tested with the so-called marker to help aid the diagnosis or monitoring of a disease or its treatment. In the case of Medco, one major product sold is an analyte that is the biologically active part of the vitamin B12 molecule, cobalamin, transported in the bloodstream.

According to the Medco website, healthcare finds itself at a crossroads where previously, doctors judged it sufficient to treat the symptoms of disease and so there was little need for diagnostic testing. Arguably, this has changed with pressure from (healthcare) payers, patients and regulators, in favour of treating the causes of disease and so necessitating a high need for diagnostic accuracy. It is against this background that the development of diagnostic testing equipment has helped to grow new companies such as our case study firm, Medco. Diagnostic work (expense), which is subject to increasing regulation, can be re-located at least in part outside of the acute hospital into the doctorôs surgery and even into the patientôs own home, the so-called point of care (POC). This possibility creates, in turn, a new corporate financial opportunity because diagnostic testing modifies the healthcare pathway to provide an income stream to diagnostic firms that provide the instrumentation and reagents for testing which is paid for by the doctor or patient at home.

The diagnostics industry has also consolidated with for example Siemens taking over DPC and Bayer amongst other acquisitions. Medcô̂ commercial director comments that:

óWhilst ten years ago, there was a relatively large number of companies operating in the bio-pharma sector, now this number has been reduced not only through mergers and acquisitions but also by firms going out of business. $\hat{~}$ 
Restructuring is commonplace with for example the US firm Abbott Labs, doing so recently after a failed takeover attempt by GE. The view of Medcoô commercial director is that the supply-side of the bio-pharma market may become more concentrated in the hands of a few major players that offer the same type of product whilst much smaller firms supply new product development, with $R \& D$ activities in the healthcare industry increasingly fragmented along the physical and financial value chain. Large players focus on ñdevelopmentò activities, whereas smaller players focus on ñresearchò activities. Moreover, a market for corporate control over small research firms has emerged.

Another important development in the industry in the last 10 years concerns the nature of competition when most of the large companies in this sector produced essentially similar product. To quote the Medco commercial director:

óThe value of a blood test has been dropped down to (the value of) a commodity. A liver function test, a bio culture test, theyôre a fraction of the price they used to be.... The suppliers to the market have allowed the customers (i.e. the hospitals and doctors) to dictate the price.ô

Competition was not restricted only to the price of the tests, but extended also to the testing instruments themselves. Customers would buy an instrument from such big names as Abbott, Johnson \& Johnson, Roche or Siemens so that price became the focus of competition rather than brand name. There is now an excess of both $R \& D$ and manufacturing capacity in the sector. However, in the view of the Medco commercial director, this situation has become unsustainable because companies cannot continue to develop new technology unless they manage to recover their initial investment. To quote the Medco commercial director on the subject:

ÓYou invest...a hundred million (pounds) in developing a new clinical analyser (but) people arenâ going to do a hundred million pounds worth of new tests. Youâe going to do the same tests whether they do it on an old machine or a new machine. You canô create blood tests out of thin air.ô

Against such a background, where Medco can add value is in the development of new disease markers. Markers become valuable when a new test has the potential to allow the doctor or 
clinician to switch from one expensive therapy that is not going to work to another (possibly cheaper) therapy that will.

\subsection{Medco: the company}

Medco was formed in the late 1990s as the result of the merger of one company based in Swindon and another firm located in the South East, which had floated on the stock exchange four year earlier. The rationale for the merger was that the two companies, previously competitors, might more profitably merge and become financially stronger. Originally, the South Eastern firm had started business as a spin-off from a local university. According to the Medco website, the company finds itself currently at a transition stage in that early in its history, the focus was on $R \& D$, with heavy investment in this area. At that time, the firm was loss making whereas now Medco is profitable and entering a ñcommercialization phaseò, with a focus on sales \& marketing and manufacturing growth. The shift into commercialization has been reinforced by the acquisition of a distribution company in a key European market in late 2007 and accounted for at fair value (market value) in Medcoôs accounts. This acquisition has extended Medcoôs distribution channels for its products.

$\mathrm{R} \& \mathrm{D}$ in Medco is about expanding the menu of diagnostic tests they offer in the point of care market but these products must be commercialized and manufacturing and marketing strategy is now focused on achieving a significant increase in manufacturing volumes. Medco employs roughly 450 employees of which 150 are employed in the South East.

\subsection{The structure and process of the R\&D activity within Medco}

In the past, the majority of research was carried out in Swindon, but the position has since reversed so that most is now done in the South East. The R\&D Director of Lab division in the South East is in charge of 25 scientists and 3 managers including Owen, who covers OEM products and works mainly with Medcô̂ largest customer, predominantly on the development side of Medcô̂ business. Another manager covers reagents whilst the third, Charles, works on new markers and so is tasked with developing the intellectual property (IP) of the company. Charles has three scientists working with him and, in turn, each scientist manages a team of researchers. The hope is that the technology that Charles is working on 
will, in time, feed through into new products. Charles works on a variety of projects, his specific brief being to investigate new markers for disease and the accompanying technologies. Medco operates in a highly regulated industry requiring detailed control of laboratory working practices and so where, the research and development process in the firm is long and convoluted. $R \& D$ is often initiated outside Medco, either in a university or a hospital, with these institutions undertaking clinical studies to explore the feasibility of new ideas for markers. After these clinical studies are completed results are then published, for review, by the medical profession who are not always receptive, given that they are also generally swamped with advertising and promotional material from the pharmaceutical industry.

Medco has an internal group scanning the environment for new ideas for markers. They are frequently contacted by outsiders with ideas some of which need to be evaluated from a commercial and a technical point of view. If there is a possibility that a new product could be commercially attractive, Medco will undertake clinical trials. In addition to longer-term R\&D projects, Medco also needs to work on shorter-term products to maintain an on-going portfolio. Short-term projects are defined as being 4-5 years in gestation and as usually involving the development of tests that will fit onto different but existing systems. The R\&D function is constrained by both market and financial imperatives, Charles commenting:

@́ne of the problems with research is that it is very easy to drift. That thereô always one more experiment you can do...the scientist in you always wants to do that.ô

He continues:

ólhe science might be fascinating but ...weôe not here just as academics. We are here to make money at the end of the day.ô

Projects, often interesting from a purely scientific perspective will be cancelled if they do not promise a commercial return. Decisions to either continue or discontinue projects would normally rest with the main board members including the Lab division R\&D director, the chief scientific officer, and depending on the project, the CEO. 
One of the three R\&D managers, Owen, is involved in the development of new products, taking them through from the research phase to what he terms ón-market.ô All of the products he is involved with are tests for automated systems, developing assays mostly for Medcoôs main customer. Company strategy is now to diversify whilst at the same time, taking advantage of opportunities offered by this main customer. Consequently, Owen talks about the need to balance the company portfolio of products into high-risk high returns and medium risk medium returns, as they go through the development process. Lab division in general tends to be seen as a cash-cow which generates the returns necessary to keep the Atlas development program going.

Owen talks of the pressures to deliver new products on time, with expectations as to launch incorporated into financial forecasts in terms of the timing of sales of new products. The $R \& D$ budget is constructed by the Lab R\&D director but there is a lot of uncertainty because it is difficult to predict what projects will be in place in a yearôs time. Often the exact budget is not clear-cut in that detail will be progressively filled in and, in the meantime, the focus will be on controlling the size of department, staff and raw materials costs. When the launch date is so important, intermediate milestones need to be in place including, for example, that a particular assay is meeting its performance requirements. Owen feels that there is a greater stress now on reaching such milestones than there was when the company was in the initial start up phase roughly ten years ago. This is especially important when the useful patent life of products is reduced and where some of Medcoôs earlier products are coming out of patent in the next few years. To quote the Medco commercial director:

ÓThereôs always going to be a need for new products, new markers. I think when that stops...also remember that weôe got this situation where the product $\mathrm{X}$ business is going to come to an end at some point.ô

In terms of key indicators the commercial directorô attention is focused on top line sales and profitability, with credit control rarely being an issue as customers, particularly the big companies, have tended to pay on time. Metrics such as the percentage of sales arising from new products, common in highly innovative firms are also not used because Medco only launches a few new markers each year. 
The commercial director who is on the main board, joined the company in 2007 , and was brought in to lead the firm towards a more sales \& marketing focused strategy.

đ was brought in here to change the sort of sales and marketing outlook....(Medco) marketing tended to have been more scientific support....the idea was that we needed to take a different approach.ô

He continues:

áMy perception of the company when I first came here was one of a group of people who werenâ necessarily talking to one another, didnâ necessarily have a common goal. So I have been involved a lot with them trying to get alignment across the organisation and put in a (balanced) scorecard matrix.ô

He further comments that when he joined Medco, there was an understanding of tasks that needed to be done but not of how these related to the business objectives of the company. In order to facilitate such understanding, he introduced a balanced scorecard within the part of the business located in the South East. The top level of the scorecard gives budgeted turnover and profitability targets to be reached in the Lab division. In order to reach these targets, assumptions about particular product launch dates for the Lab division are built into these estimates. To this end, the commercial director works with the company accountant, on the phasing of income and expenditure and the underlying assumptions in the budget. These assumptions then percolate down to the sales and marketing scorecard and that for R\&D. Partly, as a result of introducing the balanced scorecard the commercial director believes that there is now a heightened level of understanding that if a product is not launched by the target date, then the organization will not meet its budget.

The R\&D manager, Owen, comments on the effort that has gone into implementing the balanced scorecard and in reinforcing its effectiveness, including linkage to the bonus scheme:

óWell a lot of effortôs gone into that (i.e. implementing the balanced scorecard) $\ddot{i}$ basically the management team now meets on a monthly basis to review it and update it so it is a living document $\ddot{i}$ we have been using a very simple colour coding scheme ï green means itôs probably on target, red definitely means we definitely wonâ and 
orange we are somewhere in between and that is then communicated to staff on a monthly basis as well and in a newsletter, which gets in turn backed up by staff meetings and in addition to that we have quarterly all site meetings....so there is quite a strong emphasis on the involvement of staff in this so that they understand what business needs are, and how weâe going to get to them and it is also links into the site bonus scheme we have here as well.ô

Although Medco is R\&D- driven, it is also clear that there are emerging pressures to ensure that research work converts into commercial product that both recover expenses and make a profit. This change in perspective is captured in the quote below from Medcoôs company accountant. In an earlier period R\&D was a key yardstick on which to base a stock market valuation with profits part of a long-term project. Now the object is to make a profit for shareholders especially after the dot com boom.

óWe are, I suppose, a bit akin to the dot com bubble. Bio-pharma was also seen as a blockbuster for the future so a lot of our share price value was driven on the basis of future profits but in the climate since (the) dot com bubble burst itôs the shareholders are looking for real value as opposed to a theoretical value based on the dot com affair. So yes itôs important that we do achieve profitability and in the long term make a return to investors. It was seen at one time that a high level of $R \& D$ expenditure was a good thing- what we had (for) the size of the company was quite phenomenal really.ô

đ́ mean we were probably worth at that stage, our absolute level of R\&D hasnâ changed that much as a total of proportion spend, it was very, very high and that was seen as a good thing because it was all based on this future perception of growth but now itô not so much now as people are looking for real returns now... I would think it probably changed about four years ago, something like that. I mean it was a knock on effect from the dot com (bubble).ô

It is the company accountant $\hat{Q}$ view that investors are now looking for óeal returnsô in contrast to in the recent past. Feng et al (2001) draw attention to the dual standard operating during the dot.com boom where start-ups were provided with IPO (initial placement offer) and follow on investment funding on the promise of future returns. This was in stark contrast 
to the ñold economyò business model that required firms to generate 12-15 per cent return on capital employed to secure investment.

Referring to the current changed market conditions facing the firm, the R\&D director comments that whilst Medco spends a large proportion of its income on $R \& D$, it is working hard to communicate how R\&D converts into commercial income.

đ́ think this was the problem we had with the marketplace, just seeing us as a heavy spender in R\&D and this is the message weôe putting out now is that weôe done a lot of the R\&D and now we are commercializing it all and thatôs okay. But we still need to keep R\&D going because otherwise we wonâ have a future.ô

The commercial director revealed that investor analyst reports are left in the company canteen so that all employees are potentially aware of Medcoôs share price and of City expectations. To quote the commercial director:

óYeah, I think Iôre certainly noticed the difference coming from my previous employer to Medcoé in terms of the analystsôreports that are in the canteen...when everybody hears about the share price. What will the City think of this? I think there is a very strong focus on what will the City think? What will the shareholders think? And I guess you would expect that in a company like Medco...ô

Internal communications about performance play an important role in connecting $R \& D$, income, profit and company valuation, and employee bonuses reinforce the linkage.

The commercial director also provides ñgood storiesò for an external audience especially the analysts that make r̃ouy, sell or holdòrecommendations on the firmôs stock.

ÓThe pressures that there are donâ stop us doing what we are doing but youôe always got to be thinking.... ónow will this be perceived?ô...so I believe by doing that (driving product sales and helping increase profitability), I actually create the good stories to send back to the marketplace.ô

Charles, one of the research managers, is aware of financial pressures especially the significance of announcing good or bad R\&D outcomes which 
ó...can have quite an effect on the share price for example, announcements that are made, either good or bad.ô

In terms of managing such information communicated to financial markets, another senior manager, Fred, tends to get involved in ensuring that the correct scientific message is provided to financial institutions.

The company accountant observes that institutional investors have so far not placed Medco under too much pressure but the firm will have to perform in the next couple of years.

đ́ donâ think there have been many pressures, particularly from any of the institutional investors from the States because we are probably at quite an exciting stage of development.... weôe got to perform for the next couple of years.ô

Significantly, the R\&D work has been done and Medco needs to commercialize this and earn a return on the investment.

đ mean to achieve profitability for three years, that is the launching pad if you like for the growth, all these things that have been incurred, the hard work has been done. Now we have since moved over to a commercialization phase so our sales \& marketing people have to get out there and sell.ô

óWeôre got to deliver (on promises)...weôre got a little while. But there will be pressures Iôm sure (later).ô

The R\&D Director, comments:

óGood science and no sales. Thereôs no point in having the best product in the world if you canâ sell it so that whole philosophy that's changed. Weốe a commercial company and thatô developed... I respect that shareholders are looking to get their money back, looking for a return. If we donâ theyâl take their money out and invest it somewhere else.ô 
The R\&D manager, Charles also notes

óThe science might be fascinating but ...weôe not here just as academics. We are here to make money at the end of the day.ô

Conditions have changed for Medco since it started life as a spin-off of the research arm of a university located in the South East. The culture of the organization changed from an academic research driven start-up to a commercially driven business with appointed managers some of whom had come from larger pharmaceutical companies such as GSK and Abbott Labs. In 2007, a new marketing director hired to change company culture introduced the balanced scorecard into Lab division in the South East with a host of related measures, including linking financial outcomes to the site bonus scheme. Within the firm at large, there is a recognition that Medco has to deliver on its past promises to the financial markets. Maintaining R\&D spend is a central objective, both because this would help reduce Medcoôs reliance on its major customer as well as introducing new products in view of the imminent expiry of the product $\mathrm{X}$ patent in 2013. To quote the commercial director:

óWe have a lot of our business is built upon the back of product X. We get a lot of royalties from product X but our patent expires in 2013 so thatô going to make a big hole in the business of 2013.0̂

In the following section we reveal the extent to which high R\&D intensity has delivered strong financial performance and the extent to corporate governance has become financialized in Medco.

\section{Medco: financial performance 2003-2007}

Medco is an $R \& D$ intensive business recycling an average $16 \%$ of total revenues into $R \& D$ over the period 2003-2007, a commitment that is ten times greater than the average of the FTSE100 R\&D-active group of firms. (Here R\&D-active firms are defined as encompassing those FTSE100 firms which engage in any reported R\&D expenditure). For the period 20032007 Medco reinvested three-quarters of cash generated from operations into capital 
expenditure and R\&D. This is equivalent to two-thirds of all external and internal funding raised. It is possible to describe companies as being ñproductionistò or ñfinancializedò (Andersson et al 2007) where firms devote, more or less, financial resources into innovation and productive renewal. In the period 2003-2007, Medco maintained a high level of investment into $\mathrm{R} \& \mathrm{D}$ and productive renewal suggesting that óproductionistôgovernance was a priority rather than downsize and distribute (Lazonick \& OốSullivan, 2000).

Figure 1: Medco: R\&D and Capital Expenditure in Sales (\%)

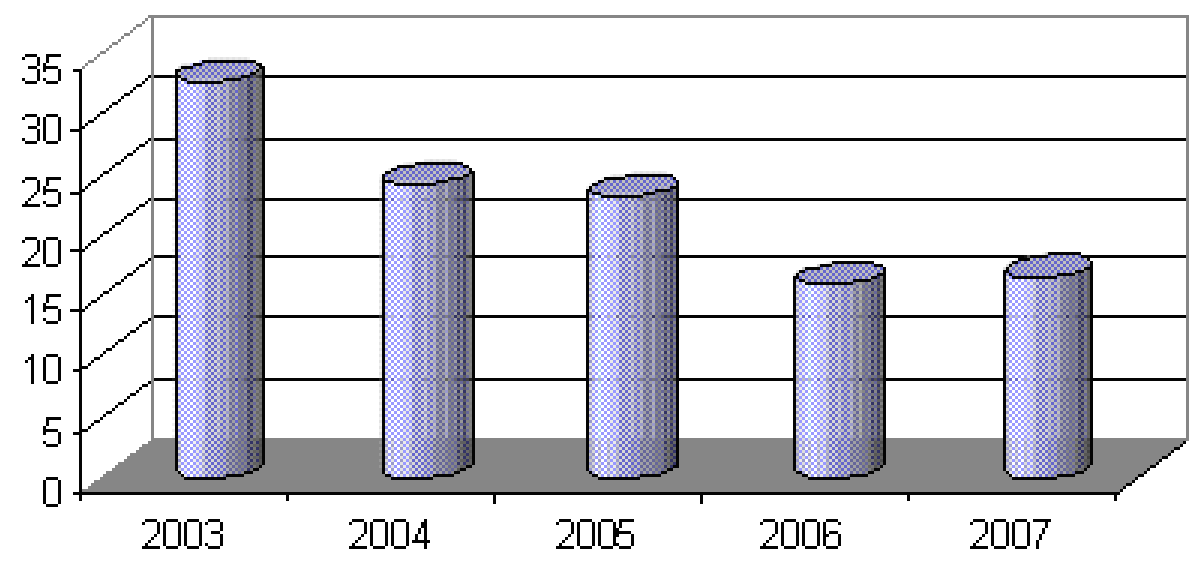

Source: Medco Annual Report 2003-2007

It is noteworthy, however, that over a relatively short period of time the reinvestment rate in $R \& D$ and capital expenditure has slowed relative to the growth in sales revenue as shown in Figure 1. Our argument is that this may reflect a re-orientation in governance and strategic priority. Before we turn to explore the extent to which Medco is shifting its strategic emphasis towards the financialization of governance and strategy, we first consider the extent to which a high $\mathrm{R} \& \mathrm{D}$ innovation-led policy is delivering above average performance.

R\&D spend and investment in additional productive and distribution capacity extended sales revenues by more than $35 \%$ over the period 2003 to 2007 but this growth rate was not exceptional. For example, Figure 2 below plots Medco sales growth against that of the FTSE 100 group of $R \& D$ active firms. 
Figure 2: Sales Growth Medco and FTSE 100 (2003-2007)

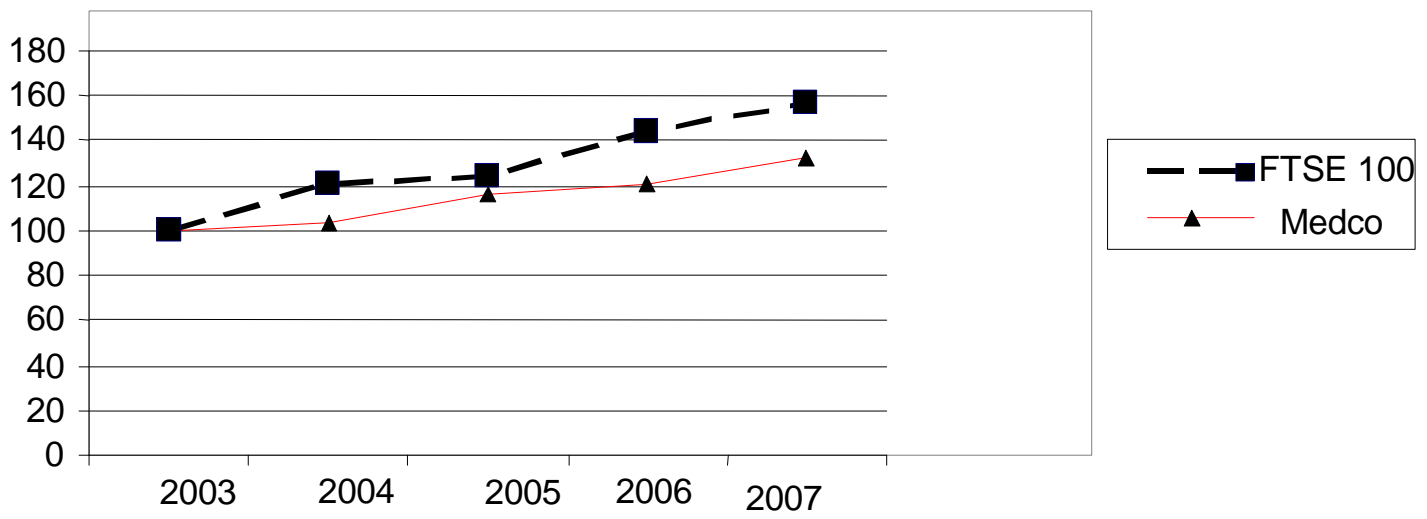

Source: Thomson One Banker

Medco operates with sales revenue of under $£ 100$ million and employment of around 450 staff (in 2007) and given the firmôs size we have chosen to benchmark it against the Alternative Investment Market (AIM) group of companies. Our analysis profiles key financial operating ratios of 500 AIM listed firms where we have 5 years of financial data for the period 2003 to 2007 . The key financial ratios employed to benchmark the performance of Medco use a nature of expenses rather than function of expense approach (see Andersson et al 2008). Starting with the revenue side we deconstruct performance to reveal how much revenue is employed to cover external and then internal costs (such as employee expenses) leaving a residual of cash and profit from operations. We then combine this analysis with rates of capitalization (debt and equity) employed to generate a unit of cash or profit per unit of capital employed (Andersson et al, 2007, 2008).

We start by considering the share of total sales revenue retained in Medco after paying out all external expenses to suppliers and providers of services. As shown in Figure 3 below, Medco progressively increased the share of revenue it retains from the financial value chain from 27 to 43 percent so that for every unit of sales revenue over half is retained in Medco compared to the Alternative Investment Market (AIM) average of roughly 28 percent. 
Figure 3: Value Retention as Percentage of Sales

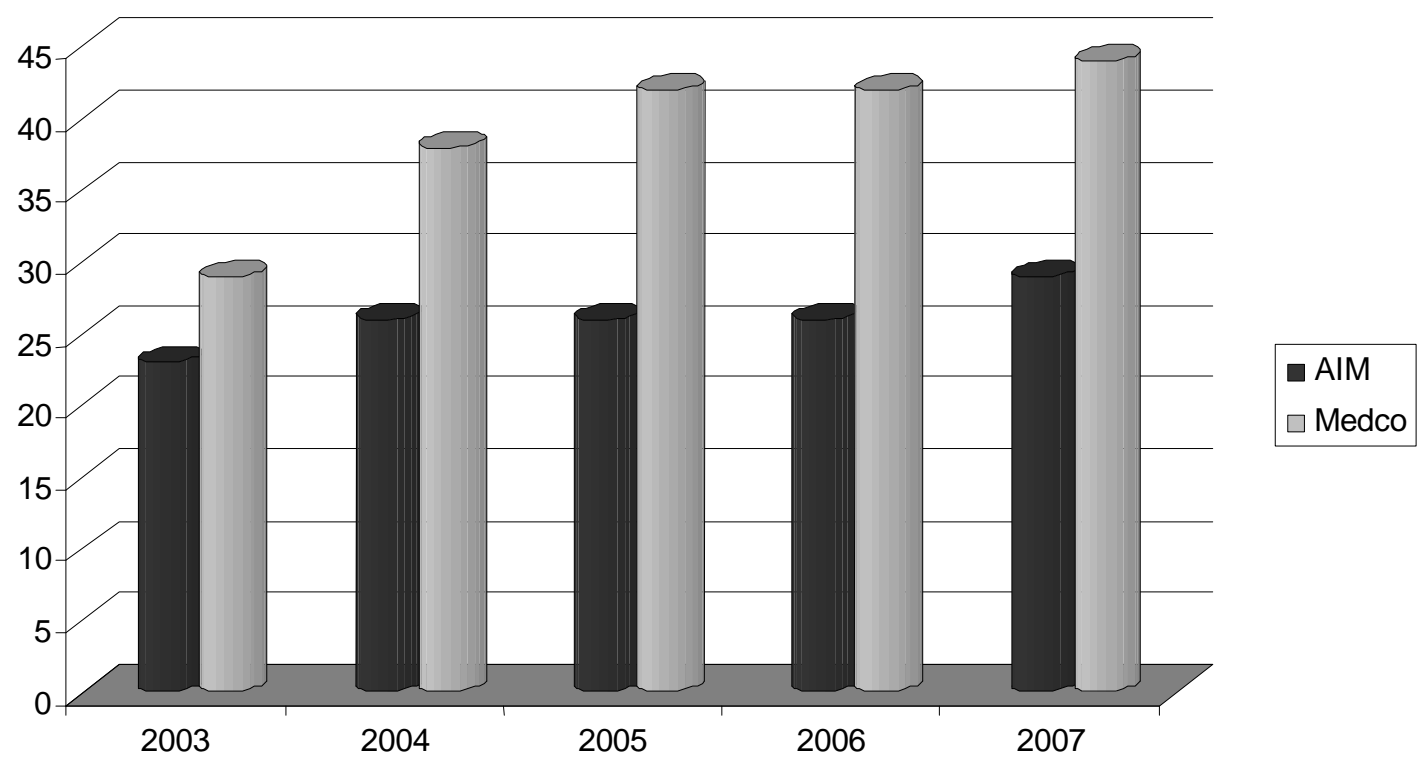

Source: Medco Annual Report 2003-2007 and Thomson One Banker

We now turn to consider the share of value retained which is distributed to remunerate employee employment including social charges. Medco operates with a high labour costs share of value retained in its start-up phase distributing more than $100 \%$ of value retained to cover employee compensation in 2003. As in Figure 4 below, by 2007 Medco distributed roughly three-quarters of value retained to its employees, a similar figure to the average AIM listed company.

This combination of both a higher share of income retained and a similar share of labour costs in revenue enabled Medco to generate a higher share of cash resources from its operations as earnings before interest, tax, depreciation and amortisation (EBITDA) relative to the average AIM listed company. 
Figure 4: Labour Cost in Value Retained (\%)

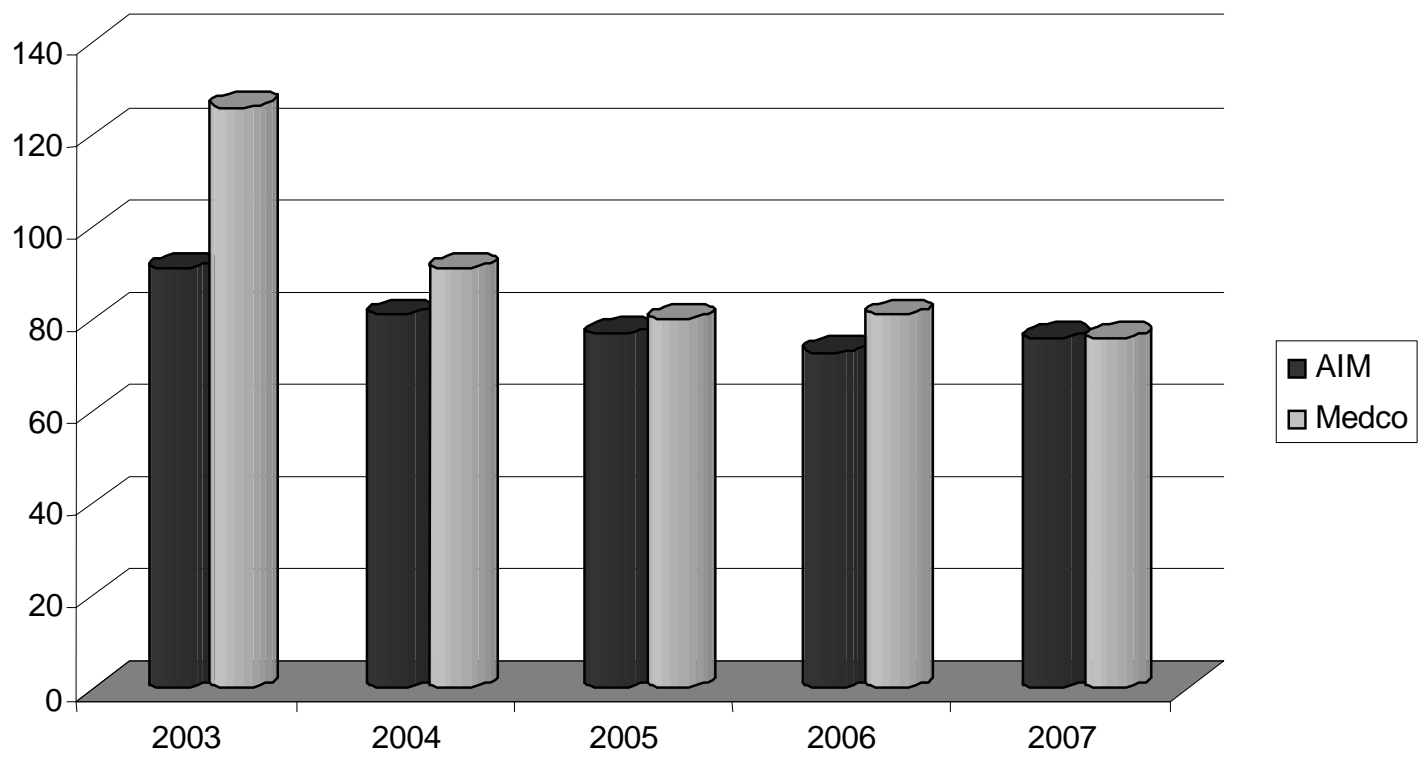

Source: Medco Annual Report 2003-2007 and Thomson One Banker

Figure 5: Cash as a Percentage of Sales

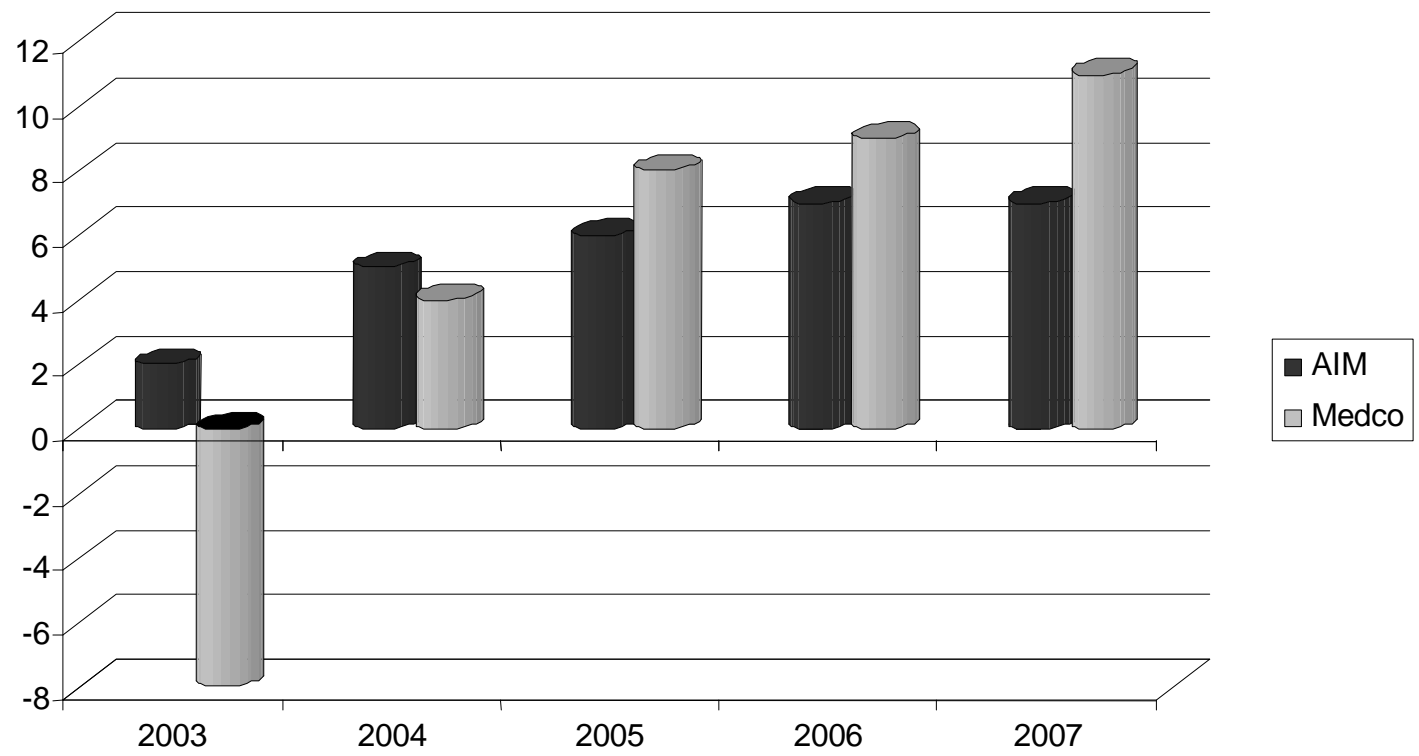

Source: Medco Annual Report 2003-2007 and Thomson One Banker 
After a start up phase when cash from operations is negative, Figure 5 above shows that Medcoôs share of cash extracted out of sales revenue increases to just over 10\% compared to the AIM average of $7 \%$. A significant bottom line ratio is the Cash ROCE that includes balance sheet capitalization (long-term debt and shareholder equity). The cash ROCE also figures in key shareholder value metrics that use a combination of cash / capital employed in their computation. Froud et al (2006) argue that it is possible for companies to under perform in ROCE terms relative to what is seen as a shareholder value norm, for example their case study of General Electric reveals that underperformance in terms of ROCE may still be rewarded favorably by the market. Anderson et al 2008 observe that the ROCE is both a product of value creating moves (cash extracted per financial unit of capital employed) and also value absorbing moves (merger and acquisitions) which are accounted for at market value often inflating balance sheet capitalization ahead of cash earnings.

Figure 6: Cash ROCE \%

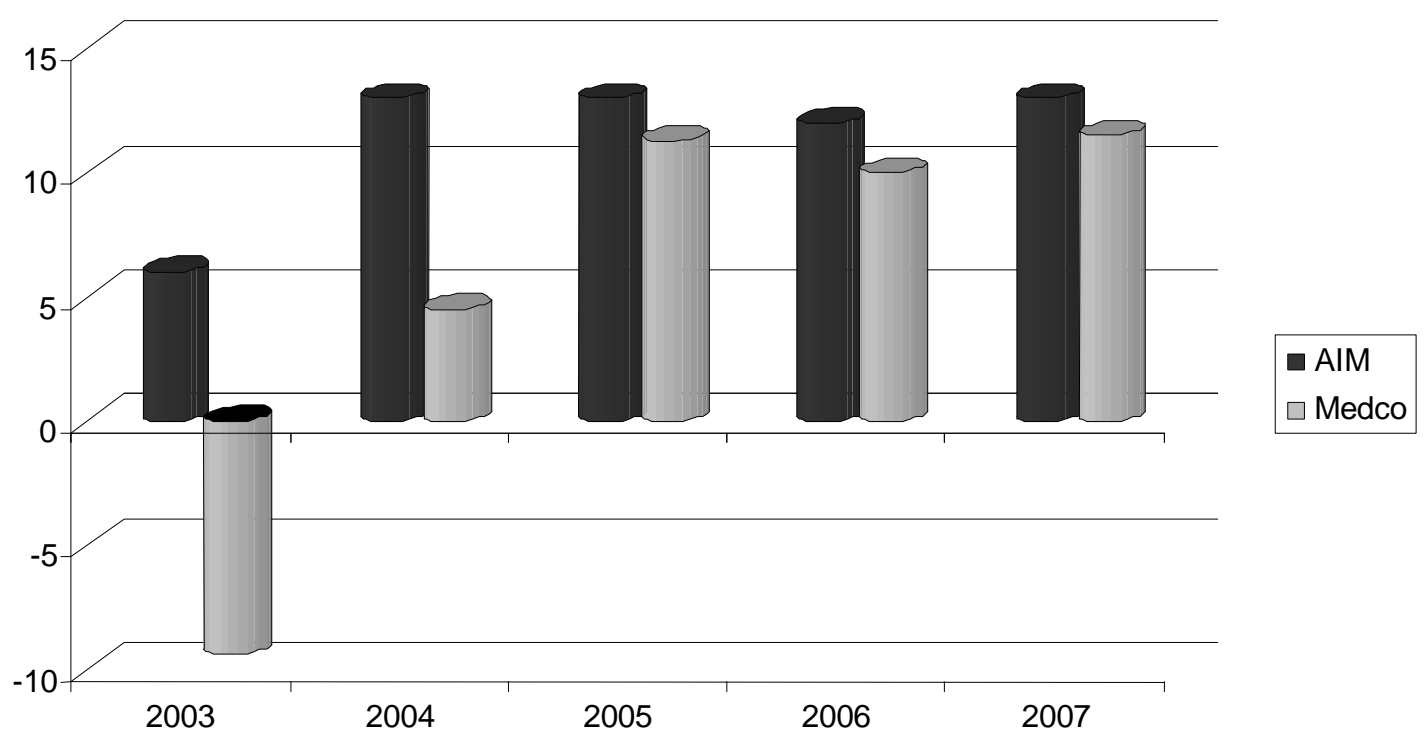

Source: Medco Annual Report 2003-2007 and Thomson One Banker

Although Medco starts off with favourable operating costs structures which release a higher share of revenues as cash (EBITDA), this does not translate into a higher cash ROCE because Medcoôs capital intensity (balance sheet capital employed per unit of sales revenue) is above the AIM average. Medco, whilst an R\&D intensive company, is not able to translate this commitment into an above average bottom line cash return on capital employed which is a 
key shareholder value metric as shown in Figure 6. In this specific case there does not seem to be a straightforward linkage between $R \& D$ intensity and above average return on capital for shareholders.

Evidence taken from Medcô̂́ annual report and accounts facilitates the construction of an alternative financialized account of corporate governance and strategic priority. Our argument is that financialization is directing governance and strategy in Medco because the objective of driving up cash earnings and stock market valuation feeds back into directorsô medium and long-term compensation and bonus arrangements. To grow cash earnings and market value from the commercialization of Medcốs products required the company to acquire distribution capacity. This transaction (the purchase of another company) accounted for at fair (market) value required managers to absorb the market value of the deal. In this account of financialization directing Medcô̂ governance and strategy, capital market claims are modifying stakeholder settlements.

We start with directorsôcompensation and bonuses. Medcô̂ remuneration report discloses that directors receive a basic fee but that they are also paid a cash bonus where certain financial and non-financial targets are met.

ñObjectives for 2007 put emphasis on superior performance against budgeted profit before tax on a Group and Divisional basis and for the Chief Executive Officer and the Finance Director, the Companyôs relative share price performanceò

This bonus payment is subject to a limit of a maximum of 60 percent of annual basic salaries. In the financial year ended 2007 the directors of Medco received $£ 2 \mathrm{~m}$ in basic fees and bonuses (of which bonuses were $£ 0.25 \mathrm{~m}$ ). This payment to directors was the equivalent of over $50 \%$ of profits earned and nearly one-quarter of the total R\&D expense in 2007 . Payments to directors do account for a substantial proportion of profit and to cross-check, we ranked the top ten AIM listed bio-pharmas by their market value and computed the total profit/loss of these firms in 2007. Many start-up bio-pharma firms are loss making (like Medco in an earlier period) and this group of ten bio-pharma companies incurred losses amounting $£ 23$ million in 2007. Directorsôfees and bonuses for this group accounted for one third of losses again suggesting that in small to medium start-up companies the emoluments and bonuses of directors constitute a substantial financial commitment out of profit and loss. 
In addition to their fees, Medco directors have been issued with stock options subject to the following conditions:

» earnings before interest, tax, depreciation and amortization (EBITDA)

must be positive for at least the two financial years immediately prior to exercise and;

$\gg$

EBITDA per share, once positive, should achieve growth which exceeds the percentage growth in the Retail Price Index by $4 \%$ or more. In addition, the growth in the Companyôs share price between date of grant and at least one day during the option period must put it in the top third of companies which comprise the All Share Health Index.

The number of stock options outstanding and issued to directors was equivalent to $4 \%$ (slightly below the AIM average of $6 \%$ ) of outstanding share capital with a market value of $£ 5 \mathrm{~m}$ of as at the year-end 2007 .

The commercialization strategy at Medco has involved a number of acquisitions totaling roughly $£ 7$ million in 2007, which has improved the firmôs distribution capacity. In financialized accounts, Andersson et al (2008) argue that the switch from historic cost (pooling of assets) to ớair valueô business combination reporting reflects the increasingly dominant interests of shareholder stakeholders. Corporate-capital market transactions are now ómarked to marketôin the balance sheet to reflect the current market value of the enterprise to shareholders. Medcố acquisition was accounted for at fair value using the purchase method in line with the International Accounting Standards Board (ISAB) regulation on accounting for business combinations.

http://www.iasb.org/NR/rdonlyres/73E562FE-F581-4DD4-8365-B17E228955C9/0/IFRS3.pdf

Mark to market accounting tends to deflate reported cash ROCE because balance sheet values inflate ahead of cash earnings when the cash earnings of the acquired company remain relatively untransformed but balance sheet values are inflated to their market value. Medcoôs acquisition resulted in the company absorbing the market value of assets where the value of goodwill on acquisition (the difference between market and book value) lodged in the balance sheet was equivalent to 20 per cent of Medcô̂ total assets employed. In addition to the impact on reported cash ROCE, goodwill is no longer annually amortized but is subject to 
a ñgoodwill impairment testò Were product market conditions to deteriorate, goodwill impairments could undermine reported profits.

Financialization is directing strategy at Medco because incentives (bonuses and stock options) modify the management of corporate resources and governance around arbitrage for value creation and absorption (Andersson et al, 2008). Medco has yet to make dividend payments to shareholders but institutional shareholders, during the current credit crisis may modify their demands. If dividends were to be paid this would unsettle the existing pattern of stakeholder claims, forcing senior executives to extract additional cash out of operations and increase available free cash resources for distribution.

Moreover, Medco is currently operating a defined benefit (DB) pension scheme where employees are entitled to a pension based on their final salary. Most DB pension schemes will have a certain proportion of their investments in share capital (Medco currently has 20\% of pension assets invested in equities) and during the bull market, holding gains inflated the value of pension fund assets. Many DB schemes were in surplus during the 1990s and often firms could take a pension holiday. In the current bear market the value of stocks (FTSE100, S\&P500) are down 30\% January 2008 to December 2008. At the end of the financial year 2007, Medco reported a pension shortfall because liabilities (claims) exceeded the valuation of assets (the value of pension investments) by roughly $£ 3 \mathrm{~m}$. In the financial year 20007 Medco included a charge of $£ 1.0 \mathrm{~m}$ (and in $2006 £ 1.5 \mathrm{~m}$ ) against profit to provide for the difference between pension fund assets and liabilities.

\section{Discussion and conclusions}

Medco is a case study of an R\&D intensive start-up operating under financialization and reflects how the demands of shareholders in an era of shareholder value become internalized aligning managerial and shareholder interests. Froud et al (2006) observe that financialization is about the discrepancy between narratives employed to exaggerate claims about improved performance to help boost stock prices and managerial pay and the financial numbers which are often not transformed.

In its development stage, Medcoôs R\&D culture was the product of being a spin out from a South Eastern University where the object was to develop ideas and publish in academic 
journals. This R\&D driven culture of experimentation, innovation and knowledge development was still present in Medco in 2008 but these values had been diluted by a managerial culture with its emphasis on commercialization and cost effectiveness, cash earnings and pay for performance. $R \& D$ does still matter in Medco but those who talked to us about $R \& D$ suggested that $R \& D$ must pay for itself and help generate returns to shareholders. The R\&D function (expense) is wired into budgets that set out the physical and financial objectives, budgets also embodying financial incentives that connect employee pay to (shareholder value) performance. $\mathrm{R} \& \mathrm{D}$ is also about communicating ñgood newsò to analysts to influence their opinions, confidence and ultimately the share price.

This article employs financial numbers to construct an alternative argument that R\&D (on its own) may not be sufficient to deliver strong corporate financial performance and that the link between $R \& D$ and financial performance is not that straightforward. These results align with the findings of the Froud et al (2006) Glaxo case where, the authors argue that high R\&D expenditure does not necessarily underwrite robust financials. Responses from our interviewees revealed some of the tensions and contradictions, for example, that Medco often struggled to get new product into the market quickly enough and how delay could eat into the effective patent period. Moreover, even before patent expiry, intense product market competition and the commodification of diagnostic tests damaged cash and profit margins.

Our analysis of the numbers from Medcô̂ published report and accounts revealed that financial performance is not exceptional when referenced to the average AIM listed firm. Medco is caught between powerful customers, competitors and vagaries of the capital market all of which make the connection between $R \& D$ intensity and robust shareholder value financials less straightforward. Our argument is that financialization is directing corporate governance and strategy in Medco and one key element of this is how narratives about R\&D in progress and completed are deployed to boost market valuation in the absence of above average performance.

Other elements include a directorsôremuneration package that wires managerial and staff bonuses into shareholder value metrics. In Medco senior executive pay was directly linked to boosting the cash earnings per share and the market value of the company and it is noteworthy that the share of profit distributed is significant. Directorsôfees were equivalent to more than half of annual net profit and one quarter of annual $R \& D$, and accumulated stock 
options had a market value of $£ 5$ million. Having reviewed a sample of ten bio-pharmas (ranked by market value) listed on AIM we find that directorsô fees, do account for a significant share of company profit and loss.

To extend market reach Medco acquired other firms but these corporate acquisitions were accounted for at market value and this helped to inflate balance sheet capitalization ahead of cash earnings, thereby eroding corporate earnings capacity (cash ROCE). In our account of an $R \& D$ intensive firm under financialization we observe that managers are struggling to both deliver value creating moves and absorb market value for shareholders. Mark to market accounting forces firms to reflect the market value of capital market transactions in the balance sheet. When asset markets are inflating the market value of a firm generally runs ahead of cash earnings and when such a firm is subsequently absorbed by the acquiring firm this acts to depress the consolidated reported ROCE. Alternatively, a bear market forces firms to recognize holding losses, for example, as pension fund liabilities run ahead of the market value of assets.

What can we conclude from the Medco case with regards to R\&D-intensive firms under financialization? Firstly, we do need to be cautious about drawing generalizations from a specific case study. It is possible that SME bio-pharmas, are operating along different trajectories and responding variably to stakeholders and the demands of the product and capital market. However, this case study does open up a series of questions that we believe require further investigation. To what extent are $R \& D$ intensive SME firms able to translate innovation and new product development into above average financial performance and robust business models? Have the patterns of cash distribution shifted over time in $R \& D$ intensive SMEôs towards shareholders at the expense of capital investment and productive renewal? Is there a culture of high pay with a high proportion of profit distributed to directors in R\&D intensive SMEs?

Our financialized account of corporate governance and strategy at Medco revealed how narratives deployed to talk up the financial promise of $R \& D$ are at variance with alternative narratives constructed out of the financial numbers. These alterative account(s) reveal a less than straightforward connection between $R \& D$ intensity and financial performance for Medco. The process of constructing a financialized account using the firms reported financials reveals how financial outcomes are the product of a complex matrix of transactions 
arising out of product, procurement, labour and capital market interventions. From this financialized perspective, contradiction and ambiguities frustrate straightforward connectivity as between $R \& D$ as input and financial performance as output. This perspective contrasts with the óproductionistôcentered views (DCMS, 1998, 2001; Lazonick and Oôsullivan, 2000, 2004; Prahalad and Hamel, 1990) which assume a more straightforward and less ambiguous connection between $\mathrm{R} \& \mathrm{D}$, corporate financial performance and national economic competitiveness. 


\section{Acknowledgements}

We would like to thank the Institute of Chartered Accountants of Scotland Research Centre for sponsoring this project under their small project scheme.

\section{References}

Andersson, T., C. Haslam, and E. Lee. 2006. Financialized accounts: Restructuring and return on the capital employed in the S\&P500. Accounting Forum 30 (1): 21-41.

Andersson, T., C. Haslam, E. Lee, and N. Tsitsianis. 2007. Financialized accounts: A stakeholder account of cash distribution in the S\&P 500 (1990ї 2005). Accounting Forum 31 (3): 217-232.

Andersson, T., C. Haslam, E. Lee, and N. Tsitsianis. 2008. Financialization directing strategy. Accounting Forum 32 (4): 261-275.

Deeg, R., and M. O'Sullivan. 2006. The Financialization of Europe: The Evolution of Finance Capital in Britain, France, Germany, and Italy. Philadelphia: American Political Science Association, Marriott, Loews Philadelphia, and the Pennsylvania Convention Center.

Department for Culture Media and Sport (DCMS).1998. Creative industries mapping document, UK: Creative Task Force.

Department for Culture Media and Sport (DCMS). 2001. Creative industries mapping document, UK: Creative Task Force.

Ezzamel, M., H. Willmott, and F. Worthington. 2008. Manufacturing shareholder value: The role of accounting in organizational transformation. Accounting, Organizations and Society 2-3: 117-140.

Feng, H., J. Froud, S. Johal, C. Haslam, and K. Williams. 2001. A new business model? The capital market and the new economy. Economy and Society 30 (4): 467-503.

Fligstein, N. 2004. The end of (shareholder value) ideology? Institute for Research on Labor and Employment Working Paper Series Paper iirwps, 116-05.

Froud, J., S. Johal, A. Leaver, and K. Williams. 2002. Financialisation, strategy and governance: or what management has become.

http://www.mngt.waikato.ac.nz/ejrot/cmsconference/2003/abstracts/criticalaccounting/Froud. pdf

Froud, J., S. Johal, A. Leaver and K. Williams. 2006. Financialization and Strategy: Narrative and Numbers. London: Routledge, Taylor and Francis.

Gleadle, P., and N. Cornelius. 2008. A case study of financialization and EVA®. Critical Perspectives on Accounting 19 (8): 1219-1238.

Lazonick, W. 2007. The US stock market and the governance of innovative enterprise, Industrial and Corporate Change 16 (6): 983-1035. 
Lazonick, W., and M. Oôsullivan. 2000. Maximising shareholder value: A new ideology for corporate governance. Economy and Society 29 (1): 13-35.

Lazonick, W., and M. Oôsullivan. 2004. Corporate governance innovation and performance in the EU, Project SOE1-CT 98-1114.

ftp://ftp.cordis.europa.eu/pub/citizens/docs/soe1-ct98-1114 21037cgep.pdf

Prahalad C, K., and G. Hamel. 1990. The core competence of the corporation. Harvard Business Review 68 (3): 79-91.

Rossman, P., and G. Greenfield. 2006. Financialization: New routes to profit, new challenges for trade unions. Labour Education, ILO Bureau for Workers' Activities 142. http://www.iufdocuments.org/www/documents/Financialization-e.pdf

Stockhammer, E. 2004. Financialization and the slowdown of accumulation. Cambridge Journal of Economics 28: 719-741.

Yin, R.K. 1984. Case study research: design and methods. Newbury Park, CA: Sage. 